\title{
Mechanisms Underlying Vasorelaxation Induced in Rat Aorta by Galetin 3,6-Dimethyl Ether, a Flavonoid from Piptadenia stipulacea (Benth.) Ducke
}

\author{
Cibério L. Macêdo ${ }^{1, \dagger}$, Luiz H. C. Vasconcelos ${ }^{1, \dagger}$, Ana C. de C. Correia ${ }^{1}$, Italo R. R. Martins ${ }^{1}$, \\ Daysianne P. de Lira ${ }^{2}$, Bárbara V. de O. Santos ${ }^{1,3}$, Fabiana de A. Cavalcante ${ }^{1,4}$ and \\ Bagnólia A. da Silva ${ }^{1,3, *}$
}

1 Programa de Pós-graduação em Produtos Naturais e Sintéticos Bioativos, Centro de Ciências da Saúde, Universidade Federal da Paraíba, João Pessoa, PB 58051-900, Brazil; E-Mails: ciberiolandim@hotmail.com (C.L.M.); henrique.luiz89@1tf.ufpb.br (L.H.C.V.); anacarolinacc@yahoo.com.br (A.C.C.C.); italo_rossi_@hotmail.com (I.R.R.M.)

2 Departamento de Farmácia, Faculdade Santa Maria (FSM), Cajazeiras, PB 58900-000, Brazil; E-Mail: daysianneplira@1tf.ufpb.br

3 Departamento de Ciências Farmacêuticas, Centro de Ciências da Saúde, Universidade Federal da Paraíba, João Pessoa, PB 58051-970, Brazil; E-Mail: barbara@ltf.ufpb.br Departamento de Fisiologia e Patologia, Centro de Ciências da Saúde, Universidade Federal da Paraíba, João Pessoa, PB 58051-970, Brazil; E-Mail: fabianacavalcante@ltf.ufpb.br

$\dagger$ These authors contributed equally to this work.

* Author to whom correspondence should be addressed; E-Mail: bagnoliasilva@yahoo.com or bagnolia@ltf.ufpb.br; Tel.: +55-83-3216-7126; Fax: +55-83-3216-7502.

External Editor: Nancy D. Turner

Received: 10 September 2014; in revised form: 17 November 2014 / Accepted: 17 November 2014 / Published: 27 November 2014

\begin{abstract}
In this study, we investigated the relaxant action of galetin 3,6-dimethyl ether (FGAL) on rat aorta. The flavonoid relaxed both PMA- and phenylephrine (Phe)-induced contractions $\left(\mathrm{pD}_{2}=5.36 \pm 0.11\right.$ and $4.17 \pm 0.10$, respectively), suggesting the involvement of PKC and Phe pathways or $\alpha_{1}$ adrenergic receptor blockade. FGAL inhibited and rightward shifted Phe-induced cumulative concentration-response curves, indicating a noncompetitive antagonism of $\alpha_{1}$ adrenergic receptors. The flavonoid was more potent in relaxing $30 \mathrm{mM} \mathrm{KCl}$ - than $80 \mathrm{mM} \mathrm{KCl}$-induced contractions $\left(\mathrm{pD}_{2}=5.50 \pm 0.22\right.$ and $\left.4.37 \pm 0.12\right)$.
\end{abstract}


The vasorelaxant potency of FGAL on Phe-induced contraction was reduced in the presence of $10 \mathrm{mM} \mathrm{TEA}^{+}$. Furthermore, in the presence of apamin, glibenclamide, $\mathrm{BaCl}_{2}$ or 4 -AP, FGAL-induced relaxation was attenuated, indicating the participation of small conductance calcium-activated $\mathrm{K}^{+}$channels $\left(\mathrm{SK}_{\mathrm{Ca}}\right)$, ATP-sensitive $\mathrm{K}^{+}$channels (KATP), inward rectifier $\mathrm{K}^{+}$channels $\left(\mathrm{K}_{\text {ir }}\right)$ and voltage-dependent $\mathrm{K}^{+}$channels $(\mathrm{Kv})$, respectively. FGAL inhibited and rightward shifted $\mathrm{CaCl}_{2}$-induced cumulative concentration-response curves in both depolarizing medium (high $\mathrm{K}^{+}$) and in the presence of verapamil and phenylephrine, suggesting inhibition of $\mathrm{Ca}^{2+}$ influx through voltage-gated calcium channels (Cav) and receptor operated channels (ROCs), respectively. Likewise, FGAL inhibited Phe-induced contractions in $\mathrm{Ca}^{2+}$-free medium, indicating inhibition of $\mathrm{Ca}^{2+}$ release from the sarcoplasmic reticulum (SR). FGAL potentiated the relaxant effect of aminophylline and sildenafil but not milrinone, suggesting the involvement of phosphodiesterase V (PDE V). Thus, the FGAL vasorelaxant mechanism involves noncompetitive antagonism of $\alpha_{1}$ adrenergic receptors, the non-selective opening of $\mathrm{K}^{+}$channels, inhibition of $\mathrm{Ca}^{2+}$ influx through $\mathrm{Cav}$ or ROCs and the inhibition of intracellular $\mathrm{Ca}^{2+}$ release. Additionally, there is the involvement of cyclic nucleotide pathway, particularly through PDE V inhibition.

Keywords: galetin 3,6-dimethyl ether; ion channels; calcium; phosphodiesterase; vasodilator

\section{Introduction}

Flavonoids are a large class of polyphenolic substances found in plants [1] known for their interesting activities in vascular diseases [2-4]. Several pharmacological effects have been described for this class of secondary metabolites, such as inhibition of enzymes involved in the synthesis of reactive oxygen species, such as xanthine oxidase, NADPH oxidase and lipoxygenase [5], increase in nitric oxide (NO) production in vascular smooth muscle [6] and spasmolytic activity in various models of smooth muscle $[7,8]$. Furthermore, some flavonoids are known for their actions on vascular tone, such as quercetin, kaempferol, luteolin, apigenin, catechin and epicatechin [1].

Galetin 3,6-dimethyl ether (FGAL) (Figure 1), a flavonoid isolated from the plant Piptadenia stipulacea (Benth.) Ducke, has exhibited some pharmacological activities, such as antiviral [9], antinociceptive and anti-inflammatory activities in mice [2], as well as non-selective spasmolytic activity in smooth muscles (e.g., guinea-pig ileum and trachea and rat uterus and aorta). Moreover, this flavonoid has shown the highest relaxant potency in rat aorta, and this effect is independent of endothelium-derived relaxant factors (EDRF) [10].

Regarding the pharmacological effects described for flavonoids, these secondary metabolites appear to be candidates for the treatment of various diseases caused by disorders of smooth muscle, especially those affecting the cardiovascular system, such as hypertension, atherosclerosis and ischemic infarction [1]. Therefore, the aim of this work was to characterize the mechanisms involved in vasorelaxation induced by the flavonoid FGAL in rat aorta. 
Figure 1. Chemical structure of galetin 3,6-dimethyl ether (FGAL).

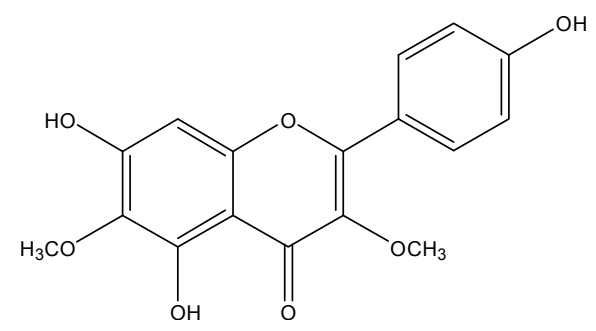

\section{Results and Discussion}

In blood vessels, the endothelium plays an important role in regulating vascular smooth muscle tone by releasing endothelium-derived relaxing factors (EDRF) [11], including endothelium-derived hyperpolarizing factor (EDHF), nitric oxide (NO), prostacyclins and epoxyeicosatrienoic acids [12]. Despite this, it was previously demonstrated that the vasorelaxation induced by FGAL is independent of EDRF, since it relaxed aorta in both the absence and presence of endothelium in an equipotent manner [10]. On the other hand, several mechanisms are involved in endothelium-independent vasorelaxation, such as $\mathrm{Ca}^{2+}$ channel blockade, $\mathrm{K}^{+}$channel opening, protein kinase $\mathrm{C}(\mathrm{PKC})$ inhibition, attenuation of $\mathrm{Ca}^{2+}$ release from the sarcoplasmic reticulum (SR) and phosphodiesterase (PDE) pathway inhibition [13]. Moreover, it has been demonstrated that flavonoids can produce vasorelaxation by different mechanisms, such as NO release from endothelium [14], PKC and PDE inhibition [15,16], blockade of $\mathrm{Ca}^{2+}$ influx through voltage-sensitive $\mathrm{Ca}^{2+}$ channels (Cav) [17] and $\mathrm{K}^{+}$channel activation $\left(\mathrm{IK}_{\mathrm{Ca}}\right.$ and $\left.\mathrm{BK} \mathrm{Ca}\right)[18,19]$.

PKC is a key protein to vascular smooth muscle contraction [20]. This protein kinase can both activate $\mathrm{Cav}$ and inhibit $\mathrm{K}^{+}$channels, leading to $\mathrm{Ca}^{2+}$ influx and contributing to the contractile process. Phorbol esters, such as phorbol 12-myristate 13-acetate (PMA), which are described as PKC stimulators, are used as exogenous activators of this protein kinase. Also, they have been known to induce sustained contraction in several arterial tissues $[21,22]$. FGAL $\left(10^{-8}\right.$ to $\left.10^{-3} \mathrm{M}\right)$ relaxed aorta pre-contracted with $3 \times 10^{-7} \mathrm{M}$ phenylephrine (Phe) $\left(\mathrm{pD}_{2}=5.36 \pm 0.11\right)$ or $10^{-6} \mathrm{M}$ PMA $\left(\mathrm{pD}_{2}=4.17 \pm 0.10\right)$. According to the $\mathrm{pD}_{2}$ values, FGAL was about 16 -fold more potent in relaxing aorta pre-contracted with Phe than with PMA. The vehicle did not show a significant relaxant effect in rat aorta pre-contracted with either contractile agent (Figure 2).

The fact that PMA and Phe elicit contraction by different pathways suggests that the relaxant effect of FGAL in rat aorta involves both mechanisms. Therefore, the flavonoid can act on PKC (PMA exclusive target) as well as $\mathrm{Cav}, \mathrm{K}^{+}$channels and $\mathrm{Ca}^{2+}$ mobilization from $\mathrm{SR}$, which are involved in Phe signaling but are not directly affected by PMA [23]. Figure 2 shows that the inhibition of PKC is possibly involved, but that other targets (e.g., Cav, $\mathrm{K}^{+}$channels or others) are involved in a major manner. Moreover, we do not discard a possible direct antagonism of $\alpha_{1}$ adrenergic receptors by FGAL.

To assess the blockade of $\alpha_{1}$ adrenergic receptors by FGAL, the effect of the flavonoid on cumulative concentration-response curves to phenylephrine $\left(10^{-11}\right.$ to $\left.3 \times 10^{-5} \mathrm{M}\right)$ was investigated. FGAL $\left(3 \times 10^{-6}\right.$ to $\left.3 \times 10^{-5} \mathrm{M}\right)$ rightward shifted these curves in a non-parallel manner with reduction in $\mathrm{E}_{\max }$ and $\mathrm{pD}_{2}$ values of phenylephrine (Table 1, Figure 3). The FGAL $\mathrm{pD}_{2}$ value in inhibiting the effect of phenylephrine was $4.94 \pm 0.04$. In presence of a noncompetitive antagonist, the agonist 
has its maximum effect suppressed and abolished at higher concentrations of the antagonist [24]. Thus, according to the data obtained, FGAL showed the profile of a noncompetitive antagonist acting on $\alpha_{1}$ adrenergic receptors, which can be associated with a blockade of downstream pathways, such as $\mathrm{Cav}, \mathrm{K}^{+}$channels and SR $\mathrm{Ca}^{2+}$ mobilization.

Figure 2. Effect of FGAL or vehicle on tonic contractions induced by $3 \times 10^{-7} \mathrm{M}$ Phe (FGAL: $\boldsymbol{\Delta}, n=5$; vehicle: $\bullet, n=3$ ) or $10^{-6}$ M PMA (FGAL: $\Delta, n=5$; vehicle: $\diamond, n=3$ ) in rat aorta. Symbols and vertical bars represent the mean \pm S.E.M., respectively. Student's $t$-test, $* * * p<0.001$ (Phe vs. PMA).

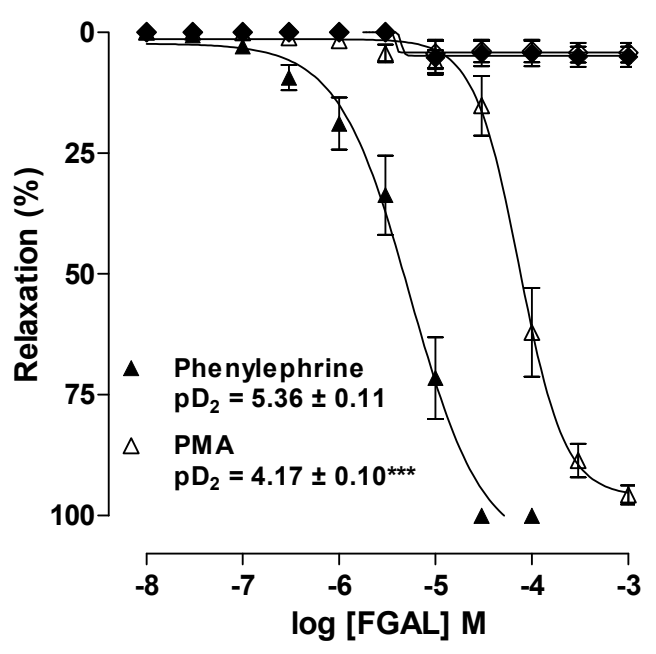

Figure 3. Cumulative concentration-response curves to phenylephrine in both the absence $(\boldsymbol{\square}$, control, $n=5)$ and presence of $3 \times 10^{-6}(\square, n=3), 10^{-5}(\bullet, n=3)$ and $3 \times 10^{-5} \mathrm{M}$ $(\circ, n=3)$ of FGAL. Symbols and vertical bars represent the mean and S.E.M., respectively.

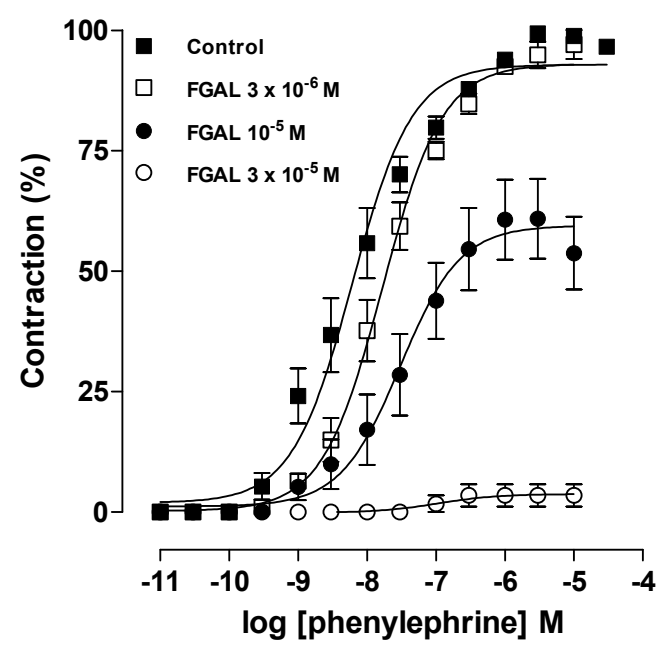

$\mathrm{K}^{+}$channel activation and Cav blockade are two important mechanisms to promote vasorelaxation and are signaling pathway targets of $\alpha_{1}$ adrenergic receptor agonists, such as phenylephrine. Thus, we investigated whether these channels would be involved in the relaxant effect of FGAL. Accordingly, we evaluated the relaxation induced by FGAL in aorta pre-contracted with high $(30$ and $80 \mathrm{mM} \mathrm{KCl})$ extracellular $\mathrm{K}^{+}$concentration $\left(\left[\mathrm{K}^{+}\right]_{\mathrm{o}}\right)[25]$. By altering $\left[\mathrm{K}^{+}\right]_{\mathrm{o}}$, it is possible to determine if a drug has 
activity as a $\mathrm{K}^{+}$channel opener or a Cav blocker, since $\mathrm{K}^{+}$channel openers are more potent in relaxing a muscle pre-contracted with $30 \mathrm{mM}$ than with $80 \mathrm{mM} \mathrm{KCl}$, because this increase in $\left[\mathrm{K}^{+}\right]_{\mathrm{o}}$ to $80 \mathrm{mM}$ prevents ion efflux, even in the case of the opening of $\mathrm{K}^{+}$channels in the plasma membrane [26].

Table 1. $\mathrm{E}_{\max }$ and $\mathrm{pD}_{2}$ values of phenylephrine in both the absence (control) and presence of FGAL $\left(3 \times 10^{-6}\right.$ to $\left.3 \times 10^{-5} \mathrm{M}\right)$ in rat aorta. Data are expressed as the mean \pm S.E.M. $(n=3)$. One-way ANOVA followed by Bonferroni's post-test: *** $p<0.001$ (control vs. FGAL), ${ }^{\#} p<0.01\left(3 \times 10^{-6}\right.$ vs. $10^{-5} \mathrm{M}$ FGAL $),{ }^{11} p<0.001\left(10^{-5} v s .3 \times 10^{-5} \mathrm{M} \mathrm{FGAL}\right)$. $\mathrm{Nd}=$ not determined.

\begin{tabular}{ccc}
\hline [FGAL] M & $\mathbf{E}_{\max } \mathbf{( \% )}$ & $\mathbf{p D}_{\mathbf{2}}$ \\
\hline Control & $100.0 \pm 0.0$ & $8.13 \pm 0.18$ \\
$3 \times 10^{-6}$ & $94.9 \pm 2.7$ & $7.75 \pm 0.10$ \\
$10^{-5}$ & $60.9 \pm 8.2 * * * \#$ & $7.49 \pm 0.16$ \\
$3 \times 10^{-5}$ & $3.5 \pm 2.3 * * * * \#$ & $\mathrm{Nd}$ \\
\hline
\end{tabular}

FGAL $\left(10^{-8}\right.$ to $\left.10^{-3} \mathrm{M}\right)$ relaxed aorta pre-contracted with both $30 \mathrm{mM} \mathrm{KCl}\left(\mathrm{pD}_{2}=5.50 \pm 0.22\right)$ and $80 \mathrm{mM}\left(\mathrm{pD}_{2}=4.37 \pm 0.12\right)$. According to the $\mathrm{pD}_{2}$ values, the flavonoid showed about 10 -fold greater relaxant potency in rat aorta pre-contracted with $30 \mathrm{mM}$ than with $80 \mathrm{mM} \mathrm{KCl}$ (Figure 4). This result indicates that FGAL activates $\mathrm{K}^{+}$channels in relaxing rat aorta.

Figure 4. Effect of FGAL on tonic contractions induced by $30 \mathrm{mM} \mathrm{KCl}(\bullet)$ or $80 \mathrm{mM} \mathrm{KCl}$ $(\circ)$ in rat aorta. Symbols and vertical bars represent mean \pm S.E.M., respectively. Student's $t$-test, ** $p<0.01(30 \mathrm{mM}$ vs. $80 \mathrm{mM} \mathrm{KCl})$.

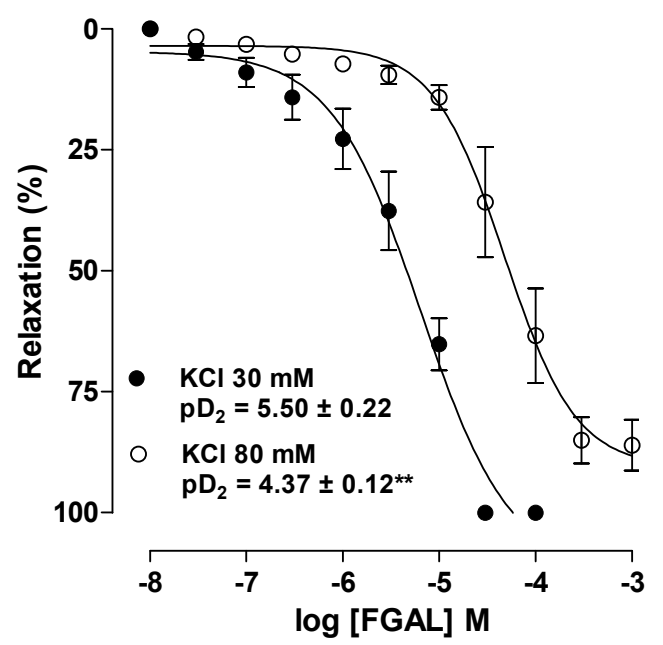

To confirm the activation of $\mathrm{K}^{+}$channels by FGAL, the non-selective blocker of these channels $\mathrm{TEA}^{+}(10 \mathrm{mM})$ was employed as a pharmacological tool. The relaxant potency of FGAL was reduced in the presence of the blocker (about 4-fold), confirming the participation of $\mathrm{K}^{+}$channels in relaxation induced by FGAL (Figure 5, Table 2). The vascular smooth muscle expresses multiple $\mathrm{K}^{+}$channel subtypes, where $\mathrm{K}_{\mathrm{ATP}}, \mathrm{K}_{\mathrm{ir}}, \mathrm{K}_{\mathrm{V}}, \mathrm{BK}_{\mathrm{Ca}}$ and $\mathrm{SK}_{\mathrm{Ca}}$ are the most expressed subtypes [27]. Hence, the involvement of these subtypes of $\mathrm{K}^{+}$channels was evaluated by employing their selective blockers. The relaxation induced by FGAL was not changed in the presence of $1 \mathrm{mM} \mathrm{TEA}^{+}$, excluding the 
participation of $\mathrm{BK}$ Ca. Conversely, the relaxant potency of the flavonoid was reduced in the presence of glibenclamide, $\mathrm{BaCl}_{2}$, 4-AP and apamin, indicating the activation of $\mathrm{K}_{\mathrm{ATP}}, \mathrm{K}_{\mathrm{ir}}, \mathrm{K}_{\mathrm{v}}$ and $\mathrm{SK}$,a, respectively, by FGAL to induce vasorelaxation in rat aorta (Table 2).

Figure 5. Representative records of relaxant effect of FGAL in rat aorta pre-contracted with $3 \times 10^{-7} \mathrm{M}$ Phe in both absence (A) and presence (B) of $10 \mathrm{mM} \mathrm{TEA}^{+}$. The arrows represent the addition of substances.

A

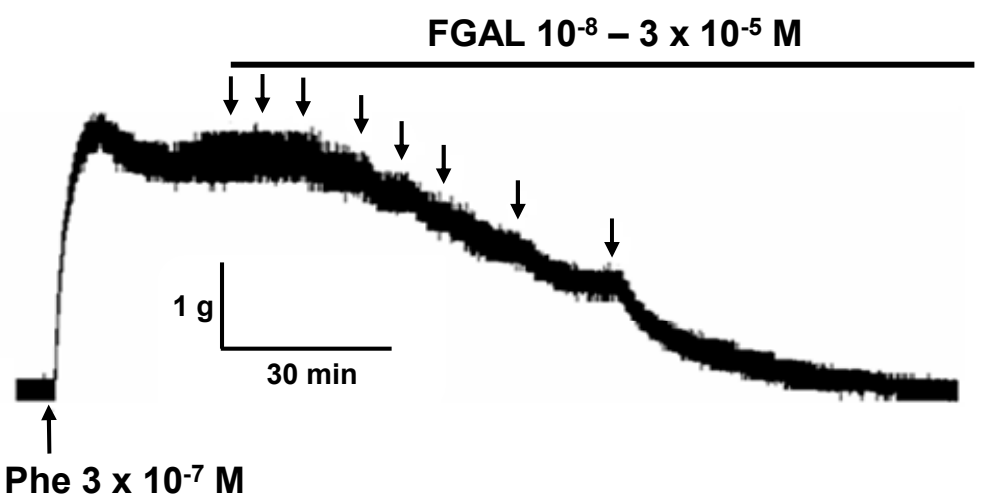

B FGAL $10^{-8}-3 \times 10^{-4} M$

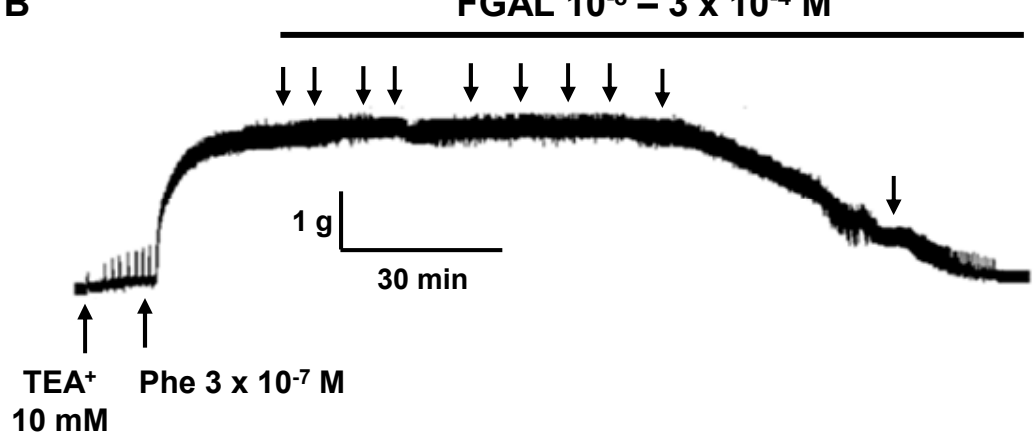

Table 2. $\mathrm{E}_{\max }(\%)$ and $\mathrm{pD}_{2}$ values of $\mathrm{FGAL}$ in both the absence and presence of $\mathrm{K}^{+}$channel blockers in rat aorta. Data are expressed as the mean \pm S.E.M. $(n=5)$. One-way ANOVA followed by Dunnett's post-test. * $p<0.05, * * p<0.01$ (FGAL vs. FGAL + blockers).

\begin{tabular}{lcc}
\hline Compounds & $\mathbf{E}_{\max }(\mathbf{\%})$ & $\mathbf{p D}_{\mathbf{2}}$ \\
\hline FGAL & $100.0 \pm 0.0$ & $5.35 \pm 0.11$ \\
$10 \mathrm{mM} \mathrm{TEA}^{+}+\mathrm{FGAL}$ & $98.7 \pm 1.3$ & $4.71 \pm 0.06 * *$ \\
$1 \mathrm{mM} \mathrm{TEA}^{+}+\mathrm{FGAL}$ & $92.8 \pm 3.4$ & $5.57 \pm 0.17$ \\
$10^{-5} \mathrm{M} \mathrm{glibenclamide}^{*} \mathrm{FGAL}$ & $98.8 \pm 1.2$ & $4.79 \pm 0.05 *$ \\
$5 \times 10^{-8} \mathrm{M}$ apamin + FGAL & $98.3 \pm 1.1$ & $4.75 \pm 0.11^{*}$ \\
$10^{-4} \mathrm{M} \mathrm{BaCl}$ \\
$+\mathrm{FGAL}$ & $89.1 \pm 4.6 *$ & $4.62 \pm 0.17 * *$ \\
$10^{-3} \mathrm{M} 4-\mathrm{AP}+\mathrm{FGAL}$ & $86.2 \pm 3.7 * *$ & $4.82 \pm 0.11^{*}$ \\
\hline
\end{tabular}

Similar results are described in the literature for other flavonoids that promote relaxation in rat aorta through the activation of $\mathrm{K}^{+}$channels; for example, pinocembrin activates $\mathrm{K}_{\mathrm{ATP}}, \mathrm{K}_{\mathrm{Ca}}$ and $\mathrm{K}_{\mathrm{V}}$ [28], (-)-epigallocatechin-3-gallate activates $\mathrm{K}_{\mathrm{ATP}}, \mathrm{SK}_{\mathrm{Ca}}$, $\mathrm{IK}_{\mathrm{Ca}}$ and $\mathrm{BK}_{\mathrm{Ca}}$ [29], and quercetin acts on $\mathrm{BK}_{\mathrm{Ca}}$ [30].

Cytosolic calcium concentration $\left(\left[\mathrm{Ca}^{2+}\right] \mathrm{i}\right)$ increase in vascular smooth muscle cell is essential for its contraction and can occur by ion influx from the extracellular medium [31] or by release from 
intracellular stores [32]. The $\mathrm{Ca}^{2+}$ influx in vascular smooth muscle cells involves the opening of Cav and ROCs [33]. Pharmacological assays showed that the tonic contraction induced by high $\left[\mathrm{K}^{+}\right]_{\mathrm{o}}$ is mainly due to the depolarization of smooth muscle cells and consequent $\mathrm{Ca}^{2+}$ influx through $\mathrm{Cav}$, while the contraction induced by Phe is caused by $\mathrm{Ca}^{2+}$ influx through both $\mathrm{Cav}$ and ROCs [34-36]. Given this and since FGAL caused more potent relaxation (about 6-fold) in aorta pre-contracted with Phe $\left(\mathrm{pD}_{2}=5.36 \pm 0.11\right)$ than that with $80 \mathrm{mM} \mathrm{KCl}\left(\mathrm{pD}_{2}=4.37 \pm 0.12\right)$, it is suggested that FGAL may reduce the $\mathrm{Ca}^{2+}$ influx through both $\mathrm{Cav}$ and ROCs.

To assess this hypothesis, we evaluated the effect of $\mathrm{FGAL}$ on $\mathrm{CaCl}_{2}$-induced contractions in depolarizing medium nominally without $\mathrm{Ca}^{2+}$ to determine the inhibition of $\mathrm{Cav}$ by the flavonoid, and its effect on $\mathrm{CaCl}_{2}$-induced cumulative concentration-response curves $\left(10^{-7}\right.$ to $\left.10^{-1} \mathrm{M}\right)$ in the presence of verapamil (Cav blocker) and Phe to determine the inhibition of ROCs. FGAL $\left(10^{-5}\right.$ to $\left.3 \times 10^{-4} \mathrm{M}\right)$ inhibited these cumulative concentration-response curvesand this effect was concentration dependent. These curves were rightward shifted in a non-parallel manner with reduction in $\mathrm{E}_{\max }$ and $\mathrm{pD}_{2}$ values of $\mathrm{CaCl}_{2}$ (Table 3, Figure 6). The $\mathrm{pD}_{2}$ value of FGAL in inhibiting the effect of $\mathrm{CaCl}_{2}$ was $4.44 \pm 0.05$.

Table 3. Emax and $\mathrm{pD}_{2}$ values of $\mathrm{CaCl}_{2}$ in both the absence (control) and presence of FGAL $\left(10^{-5}\right.$ to $\left.3 \times 10^{-4} \mathrm{M}\right)$ in rat aorta. Data are expressed as the mean \pm S.E.M. $(n=5)$. One-way ANOVA followed by Bonferroni's post-test: ** $p<0.01$ and $* * * p<0.001$ (control vs. FGAL), ${ }^{\# \#} p<0.001\left(10^{-5}\right.$ vs. $3 \times 10^{-5}$ M FGAL), ${ }^{¥ ¥} p<0.001\left(3 \times 10^{-5} v s\right.$. $10^{-4} \mathrm{M}$ FGAL). $\mathrm{Nd}=$ not determined.

\begin{tabular}{ccc}
\hline [FGAL] M & $\mathbf{E}_{\mathbf{m a x}}(\mathbf{\%})$ & $\mathbf{p D}_{\mathbf{2}}$ \\
\hline Control & $100.0 \pm 0.0$ & $2.52 \pm 0.10$ \\
$10^{-5}$ & $94.3 \pm 2.7$ & $1.95 \pm 0.12 * *$ \\
$3 \times 10^{-5}$ & $61.7 \pm 8.1 * * * \# \#$ & $2.69 \pm 0.08$ \\
$10^{-4}$ & $9.7 \pm 1.9 * * * * *$ & $\mathrm{Nd}$ \\
$3 \times 10^{-4}$ & $1.1 \pm 0.8 * * *$ & $\mathrm{Nd}$ \\
\hline
\end{tabular}

Figure 6. Cumulative concentration-response curves to $\mathrm{CaCl}_{2}$ in depolarizing medium (high $\mathrm{K}^{+}$) nominally without $\mathrm{Ca}^{2+}$ in both the absence ( $\mathbf{m}$, control, $n=5$ ) and presence of $10^{-5}(\square, n=5), 3 \times 10^{-5}(\bullet, n=5), 10^{-4}(\circ, n=5)$ and $3 \times 10^{-4} \mathrm{M}(\boldsymbol{\Lambda}, n=5)$ of FGAL. Symbols and vertical bars represent the mean and S.E.M., respectively.

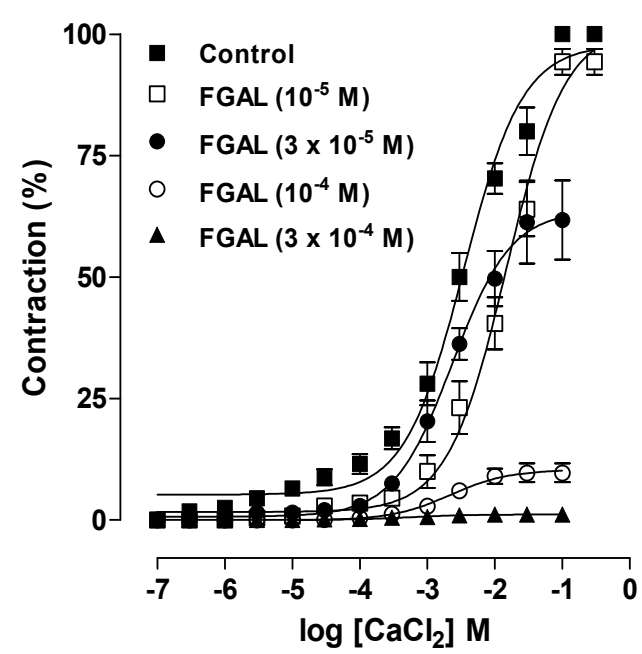


In a similar way, FGAL $\left(3 \times 10^{-6}\right.$ to $\left.3 \times 10^{-5} \mathrm{M}\right)$ inhibited $\mathrm{CaCl}_{2}$-induced cumulative contractions $\left(10^{-5}\right.$ to $\left.3 \times 10^{-1} \mathrm{M}\right)$ in the presence of verapamil and Phe (Table 4, Figure 7). The FGAL $\mathrm{pD}_{2}$ value in inhibiting the effect of $\mathrm{CaCl}_{2}$ was $5.07 \pm 0.06$. Together, these results confirm that FGAL inhibits $\mathrm{Ca}^{2+}$ influx by blocking both $\mathrm{Cav}$ and ROCs to relax vascular smooth muscle. However, comparing the inhibitory effect of FGAL in Figures 6 and 7, the potency of the flavonoid was higher in the presence of verapamil and Phe than in their absence. This therefore indicates that FGAL acts mainly by inhibiting ROCs.

Table 4. $\mathrm{E}_{\max }$ and $\mathrm{pD}_{2}$ values of $\mathrm{CaCl}_{2}$ in the presence of verapamil $\left(10^{-6} \mathrm{M}\right)$ and Phe $\left(10^{-6} \mathrm{M}\right)$, in both the absence (control) and presence of FGAL $\left(3 \times 10^{-6}\right.$ to $\left.3 \times 10^{-5} \mathrm{M}\right)$ in rat aorta. Data are expressed as the mean \pm S.E.M. $(n=5)$. One-way ANOVA followed by Bonferroni's post-test: * $p<0.05, * * p<0.01$ and $* * * p<0.001$ (control vs. FGAL), \#\#\# $p<0.001\left(3 \times 10^{-6}\right.$ vs. $10^{-5}$ M FGAL $), p^{¥ ¥ ¥}<0.001\left(10^{-5}\right.$ vs. $3 \times 10^{-5}$ M FGAL $)$. $\mathrm{Nd}=$ not determined.

\begin{tabular}{ccc}
\hline [FGAL] M & $\mathbf{E}_{\mathbf{m a x}}(\mathbf{\%})$ & $\mathbf{p D}_{\mathbf{2}}$ \\
\hline Control & $100.0 \pm 0.0$ & $2.97 \pm 0.09$ \\
$3 \times 10^{-6}$ & $81.3 \pm 4.6^{* *}$ & $2.28 \pm 0.18^{*}$ \\
$10^{-5}$ & $47.6 \pm 4.6^{* * *} \# \#$ & $2.43 \pm 0.20$ \\
$3 \times 10^{-5}$ & $4.1 \pm 1.9 * * * \# \%$ & $\mathrm{Nd}$ \\
\hline
\end{tabular}

Figure 7. Cumulative concentration-response curves to $\mathrm{CaCl}_{2}$ in the presence of verapamil $\left(10^{-6} \mathrm{M}\right)$ and Phe $\left(10^{-6} \mathrm{M}\right)$, in both the absence $(\boldsymbol{m}$, control, $n=5)$ and presence of $3 \times 10^{-6}$ $(\square, n=5), 10^{-5}(\bullet, n=5)$ and $3 \times 10^{-5} \mathrm{M}(\circ, n=5)$ of FGAL. Symbols and vertical bars represent the mean and S.E.M., respectively.

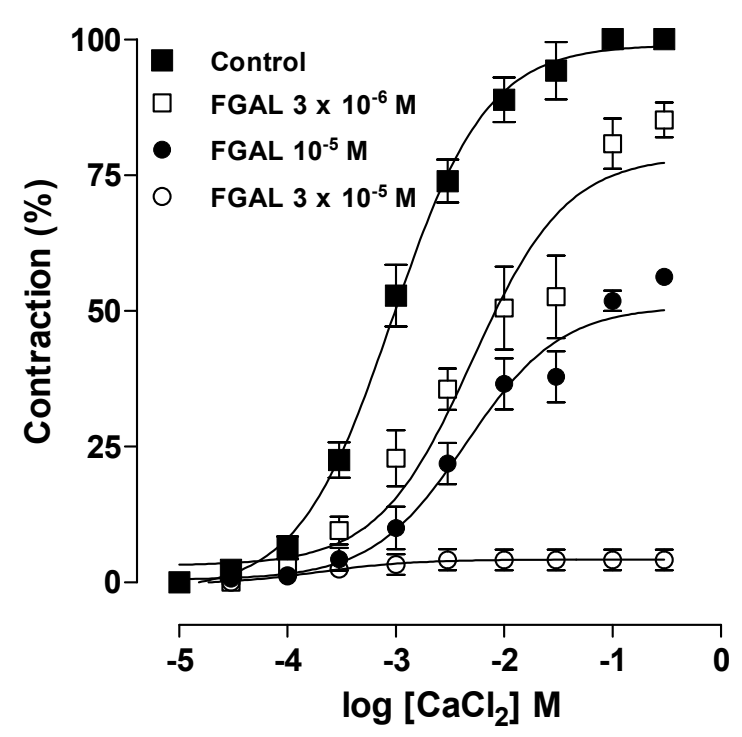

Increase in $\left[\mathrm{Ca}^{2+}\right]$ i may also occur due to $\mathrm{Ca}^{2+}$ release from intracellular stores, especially SR [37]; hence, in $\mathrm{Ca}^{2+}$-free medium, Phe-induced contraction occurs mainly due to $\mathrm{Ca}^{2+}$ release from SR. As can be seen in Figure 8, FGAL inhibited Phe-induced contractions in $\mathrm{Ca}^{2+}$-free medium in 
a concentration-dependent manner $\left(\mathrm{E}_{\max }=96.6 \% \pm 1.5 \%\right.$; $\left.\mathrm{IC}_{50}=1.0 \pm 0.1 \times 10^{-5} \mathrm{M}\right)$, supporting our hypothesis that the relaxant effect of FGAL involves the inhibition of $\mathrm{Ca}^{2+}$ release from $\mathrm{SR}$.

Figure 8. Effect of FGAL on contractions induced by $10^{-6} \mathrm{M}$ Phe in $\mathrm{Ca}^{2+}$-free medium in rat aorta. One-way ANOVA followed by Bonferroni's post-test, *** $p<0.001$ (control $v s$. FGAL), ${ }^{\# \#} p<0.001\left(3 \times 10^{-6}\right.$ vs. $10^{-5} \mathrm{M}$ FGAL $), p^{¥ ¥}<0.01\left(10^{-5}\right.$ vs. $3 \times 10^{-5} \mathrm{M}$ FGAL $)$, $\S \S p<0.001\left(3 \times 10^{-5}\right.$ vs. $10^{-4} \mathrm{M}$ FGAL $), n=5$.

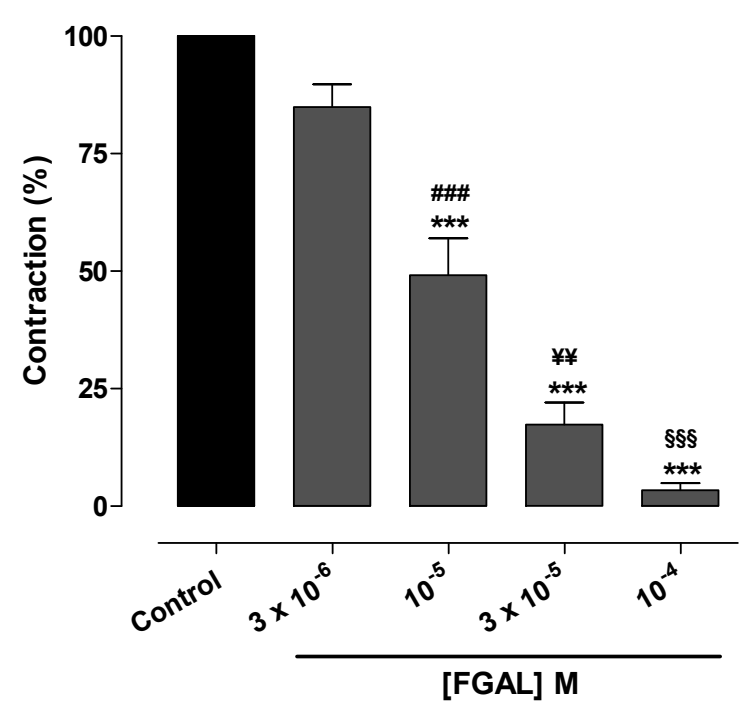

PDEs are widely distributed in mammalian tissues and hydrolyze cAMP and cGMP, resulting in their inactive products 5'-AMP and 5'-GMP, which do not activate PKA and PKG, respectively, thus stopping the cell signaling mechanism dependent on increased cyclic nucleotides [38]. Substances able to raise intracellular levels of cAMP or cGMP show a strong relaxant effect, which can be due to PDE inhibition [39]. Some flavonoids from different plant species inhibit PDEs [40], for instance (-)-epigallocatechina-3-gallate in rat aorta [29].

Therefore, to assess the possible involvement of cyclic nucleotide-PDE pathway, we determined the relaxant effect of aminophylline, a non-selective PDE inhibitor, in both the absence and presence of FGAL. The relaxant effect induced by aminophylline $\left(10^{-10}\right.$ to $10^{-3} \mathrm{M}$, positive control $)\left(\mathrm{pD}_{2}=4.36 \pm 0.09\right)$ was potentiated about 4 -fold in the presence of FGAL $\left(\mathrm{pD}_{2}=5.13 \pm 0.24\right)$, confirming that FGAL inhibits cyclic nucleotide-PDE pathways to relax rat aorta. Additionally, in vascular smooth muscle, PDE III and V are the most expressed PDE subtypes [38], and interestingly, the relaxation curve induced by sildenafil $\left(10^{-8}\right.$ to $\left.10^{-4} \mathrm{M}\right)\left(\mathrm{pD}_{2}=6.84 \pm 0.25\right)$, a PDE V inhibitor, was potentiated about 9-fold in the presence of FGAL $\left(\mathrm{pD}_{2}=7.62 \pm 0.22\right)$; however, the relaxation induced by milrinone $\left(10^{-8}\right.$ to $\left.3 \times 10^{-4} \mathrm{M}\right)\left(\mathrm{pD}_{2}=7.23 \pm 0.23\right)$, a PDE III inhibitor, was not changed in the presence of the flavonoid $\left(\mathrm{pD}_{2}=7.28 \pm 0.09\right)$ (Figure 9).

Thus, these results indicate that PDE V but not PDE III pathway is involved in relaxation induced by FGAL in rat aorta. 
Figure 9. Effect of aminophylline $(\mathbf{A}, \bullet)$ sildenafil $(\mathbf{B}, \mathbf{\Delta})$ and milrinone $(\mathbf{C}, \mathbf{\square})$ on tonic contractions induced by $3 \times 10^{-7} \mathrm{M}$ Phe in both the absence and presence of $3 \times 10^{-6} \mathrm{M}$ FGAL ( $\circ, \Delta$ and $\square$, respectively). Symbols and vertical bars represent the mean and S.E.M., respectively. Student's $t$-test, ${ }^{*} p<0.05$ (aminophylline/sildenafil vs. FGAL + aminophylline/sildenafil), $n=5$.
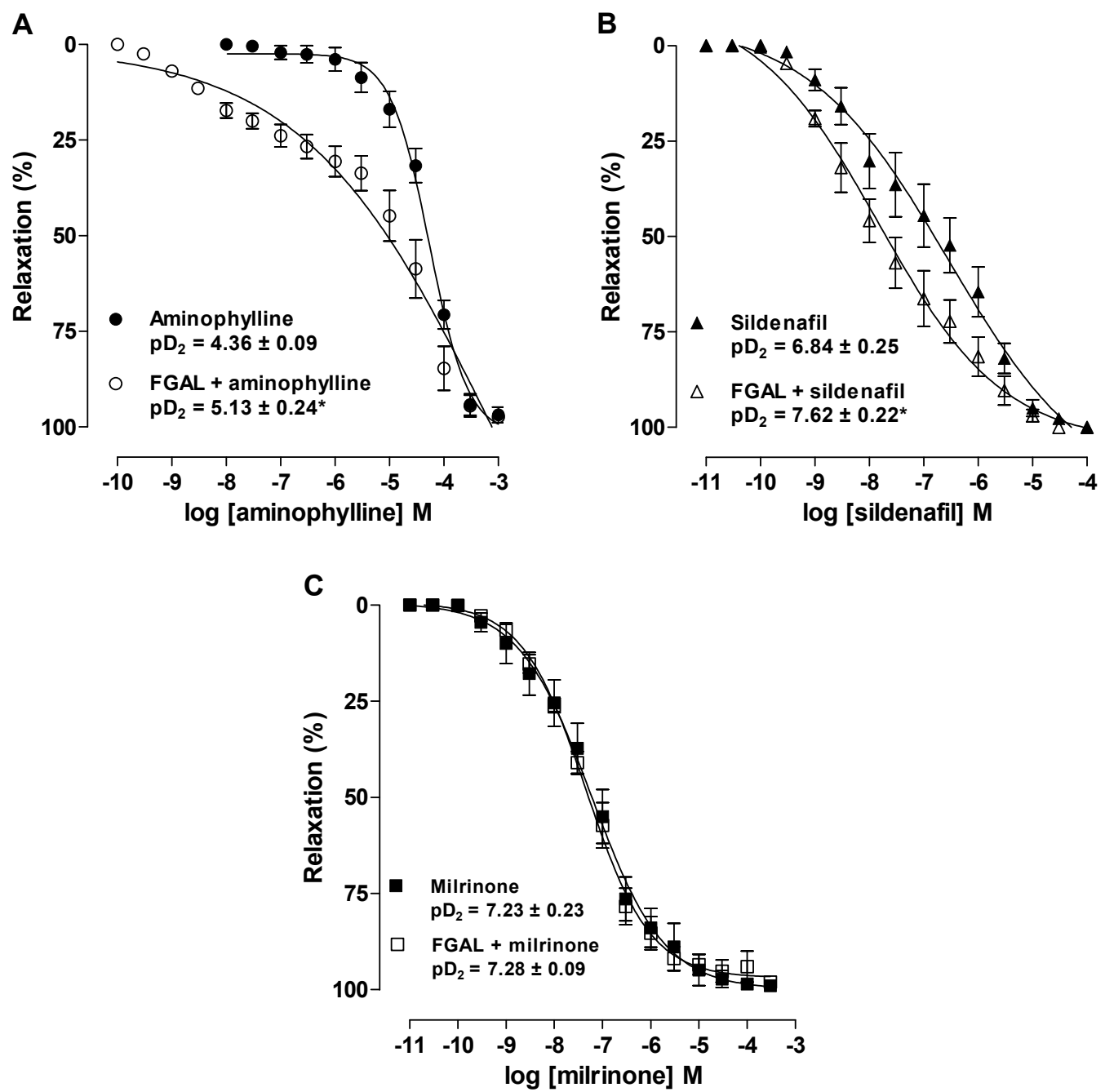

\section{Experimental}

\subsection{Chemicals}

The flavonoid FGAL was obtained according to the reported method [2]. Aminophylline, apamin, barium chloride $\left(\mathrm{BaCl}_{2}\right)$, Cremophor $\mathrm{EL}^{\circledR}$, glibenclamide, phenylephrine (Phe), phorbol 12-myristate-13-acetate (PMA), tetraethylammonium chloride $\left(\mathrm{TEA}^{+}\right)$, verapamil and 4-aminopyridine (4-AP) were obtained from Sigma-Aldrich (Duque de Caxias, RJ, Brazil). Milrinone was obtained from Sanofi-Aventis (São Paulo, SP, Brazil) and sildenafil was obtained from Nutrifarm (São Paulo, SP, Brazil). All substances were dissolved in distilled water, except glibenclamide, which was dissolved in ethanol and diluted in distilled water, and FGAL, which was dissolved in 3\% Cremophor $\mathrm{EL}^{\circledR}$ and diluted in distilled water to $10^{-2} \mathrm{M}$ and further diluted according to concentration required for each experimental protocol. The final concentration of Cremophor $\mathrm{EL}^{\circledR}$ in the organ bath never 
exceeded $0.3 \%(\mathrm{v} / \mathrm{v})$, which was demonstrated to be devoid of significant observable effects on vascular muscle tone (Figure 2).

\subsection{Animals}

Male Wistar rats (Rattus norvegicus) weighing 250-350 g from Bioterium Professor Thomas George of Centro de Biotecnologia (CBiotec/UFPB) were used. The animals were maintained in a $12 \mathrm{~h}$ light/dark cycle (lights on: 06:00-18:00 h), under controlled temperature $\left(21 \pm 1^{\circ} \mathrm{C}\right.$ ), with free access to food and water. Animal welfare and experimental procedures were followed in accordance with the Ethical Principles for Care and Use of Laboratory Animals of the Brazilian Society for Laboratory Animal Science, approved by the Animal Research Ethics Committee (CEPA) of "Laboratório de Tecnologia Farmacêutica" (LTF/UFPB, protocol 0105/10).

\subsection{Preparation of Rat Aortic Rings}

The animals were euthanized by cervical dislocation followed by sectioning of cervical vessels. Rat aorta was immediately removed, immersed in Krebs solutions and bubbled with carbogen mixture (95\% $\mathrm{O}_{2}$ and 5\% $\mathrm{CO}_{2}$ ). The Krebs solution composition was $(\mathrm{mM}): \mathrm{NaCl}$ (118.0), $\mathrm{KCl}$ (4.55), $\mathrm{MgSO}_{4}$ (5.7), $\mathrm{KH}_{2} \mathrm{PO}_{4}$ (1.1), $\mathrm{CaCl}_{2}$ (2.52), $\mathrm{NaHCO}_{3}$ (25.0) and glucose (11.0), with pH adjusted to 7.4. The Krebs depolarizing solution nominally without $\mathrm{Ca}^{2+}$ was made with $80 \mathrm{mM} \mathrm{KCl}$ in equimolar exchange for $\mathrm{NaCl}$, and the $\mathrm{Ca}^{2+}$-free Krebs solution with the addition of $3 \mathrm{mM}$ EDTA, both with omission of $\mathrm{CaCl}_{2}$. Aortic rings $(2-3 \mathrm{~mm})$ were immersed in organ baths with $5 \mathrm{~mL}$ of Krebs solution, at $37^{\circ} \mathrm{C}$ and bubbled with carbogen mixture.

To record isometric contractions, aortic segments were suspended with steel rods and connected to force transducers (FORT-10) attached to an amplifier (TMB4M), both from World Precision Instruments (Sarasota, FL, USA) and connected to an A/D converter into a PC running Biomed ${ }^{\circledR}$ software (BioData, Ribeirão Preto, SP, Brazil). The resting time of aorta was $60 \mathrm{~min}$ in a preload tension of $1 \mathrm{~g}$ (baseline). During the organ resting phase, the solution was changed every 15 min to avoid metabolite accumulation. In the experiments, the integrity of endothelium was not verified, since the relaxant effect exhibited by FGAL was similar either in its absence and presence [10].

\subsection{Experimental Protocols}

\subsubsection{Effect of FGAL on Rat Aorta Pre-Contracted with Phe or PMA}

After the initial procedures, a contraction was evoked with $3 \times 10^{-7} \mathrm{M}$ Phe or $10^{-6} \mathrm{M}$ phorbol 12-myristate 13-acetate (PMA), a protein kinase C (PKC) activator [41]. During the sustained phase of the contraction, FGAL $\left(10^{-8}\right.$ to $\left.10^{-3} \mathrm{M}\right)$ or the vehicle (distilled water + Cremophor $\left.{ }^{\circledR}\right)$ was cumulatively added to obtain a concentration-response curve [29]. The relaxation induced by FGAL was expressed as the reverse percentage of the initial contraction induced with both contractile agents, and the $\mathrm{pD}_{2}$ values of FGAL were calculated and compared. 


\subsubsection{Effect of FGAL on Phenylephrine-Induced Cumulative Contractions}

After the stabilization period, two consecutive and similar cumulative concentration-response curves for Phe $\left(10^{-10}\right.$ to $\left.3 \times 10^{-5} \mathrm{M}\right)$ were obtained in the absence of FGAL (control). FGAL $\left(3 \times 10^{-6}\right.$ to $10^{-5}$ and $3 \times 10^{-5} \mathrm{M}$ ) was then added at different concentrations and preparations for $15 \mathrm{~min}$, and a third cumulative concentration-response curve with Phe was obtained. Each preparation was exposed to only one FGAL concentration. The maximum amplitude of concentration-response curves for Phe was considered as $100 \%$ (control), and all contractions in the presence of FGAL were assessed referring to it. The $\mathrm{pD}_{2}$ value of Phe was calculated on the basis of the $\mathrm{E}_{\max }$ reached in the presence of different concentrations of FGAL [42].

\subsubsection{Effect of FGAL on Rat Aorta Pre-Contracted with $\mathrm{KCl}(30$ or $80 \mathrm{mM})$}

After the resting period, a contraction was evoked with $3 \times 10^{-7} \mathrm{M}$ Phe to test the organ responsiveness and maximum tension. Thirty minutes later, a second contraction was evoked with 30 or $80 \mathrm{mM} \mathrm{KCl}$. During the sustained phase of the contraction, FGAL $\left(10^{-8}\right.$ to $\left.10^{-3} \mathrm{M}\right)$ was cumulatively added to obtain a relaxation curve. The relaxation induced by FGAL was expressed as the reverse percentage of the initial contraction elicited with 30 or $80 \mathrm{mM} \mathrm{KCl}$, and the $\mathrm{pD}_{2} \mathrm{values}_{\text {of }}$ FGAL were calculated and compared [26].

\subsubsection{Effect of FGAL on Rat Aorta Pre-Contracted with Phe in Both Absence and Presence of $\mathrm{K}^{+}$ Channel Blockers}

After the initial procedures, a contraction was evoked with $3 \times 10^{-7} \mathrm{M}$ Phe in both the absence (control) and presence of $10 \mathrm{mM} \mathrm{TEA}^{+}$, a non-selective $\mathrm{K}^{+}$channel blocker [43]; $1 \mathrm{mM} \mathrm{TEA}^{+}$, a BK $\mathrm{Ca}$ blocker [43]; $10^{-5} \mathrm{M}$ glibenclamide, a KATP blocker [44]; $10^{-4} \mathrm{M} \mathrm{BaCl}_{2}$, a Kir blocker [25]; $10^{-3} \mathrm{M}$ 4-AP, a Kv blocker [45] and $5 \times 10^{-8} \mathrm{M}$ apamin, a SKCa blocker [46], in independent experiments, which were added to the organ baths $20 \mathrm{~min}$ before the Phe-induced contraction. During the sustained phase of the contraction, FGAL $\left(10^{-8}\right.$ to $\left.3 \times 10^{-4} \mathrm{M}\right)$ was cumulatively added to obtain a relaxation curve.

The relaxation induced by FGAL was expressed as the reverse percentage of the initial contraction induced with the agonist. The $\mathrm{pD}_{2}$ values of FGAL were calculated and compared.

3.4.5. Effect of FGAL on $\mathrm{CaCl}_{2}$-Induced Cumulative Contractions in Depolarizing Medium ( $80 \mathrm{mM}$ $\mathrm{KCl}$ ) Nominally $\mathrm{Ca}^{2+}$-free

After the stabilization period, the Krebs solution was replaced by a Krebs depolarizing solution nominally $\mathrm{Ca}^{2+}$-free for $45 \mathrm{~min}$. After this period, two consecutive and similar cumulative concentration-response curves with $\mathrm{CaCl}_{2}$ were obtained in the absence of FGAL (control). Then, FGAL $\left(10^{-5}, 3 \times 10^{-5}, 10^{-4}\right.$ and $\left.3 \times 10^{-4} \mathrm{M}\right)$ was added, at different concentrations and in different preparations, for $15 \mathrm{~min}$, and a third cumulative concentration-response curve with $\mathrm{CaCl}_{2}$ $\left(10^{-7}\right.$ to $\left.10^{-1} \mathrm{M}\right)$ was obtained [47]. The $\mathrm{E}_{\max }$ obtained with the control was taken as $100 \%$, and all concentration-response curves in the presence of FGAL were assessed referring to it. The $\mathrm{pD}_{2}$ value of $\mathrm{CaCl}_{2}$ was calculed based on the $\mathrm{E}_{\max }$ reached in the presence of different concentrations of FGAL. 
3.4.6. Effect of FGAL on $\mathrm{CaCl}_{2}$-Induced Cumulative Contractions in the Presence of Verapamil and Phe

After the stabilization period, Krebs solution was replaced by a Krebs solution nominally $\mathrm{Ca}^{2+}$-free for $45 \mathrm{~min}$. Next, $10^{-6} \mathrm{M}$ verapamil was added to the organ bath for $10 \mathrm{~min}$, followed by a contraction induced with $10^{-6} \mathrm{M}$ Phe. Ten minutes later, two consecutive and similar cumulative concentration-response curves with $\mathrm{CaCl}_{2}\left(10^{-5}\right.$ to $\left.3 \times 10^{-1} \mathrm{M}\right)$ were obtained in the absence of FGAL (control). The preparations were then washed with Krebs solution nominally $\mathrm{Ca}^{2+}$-free, $10^{-6} \mathrm{M}$ verapamil was added to the organ bath for $10 \mathrm{~min}$, FGAL $\left(3 \times 10^{-6}, 10^{-5}\right.$, and $\left.3 \times 10^{-5} \mathrm{M}\right)$ was incubated at different concentrations and in different preparations, and a third cumulative concentration-response curve with $\mathrm{CaCl}_{2}$ was obtained [48]. The Emax obtained with the control was taken as $100 \%$, and all concentration-response curves to $\mathrm{CaCl}_{2}$ in the presence of FGAL were assessed referring to it. The $\mathrm{pD}_{2}$ value of $\mathrm{CaCl}_{2}$ was determined on the basis of the Emax obtained in the presence of different concentrations of FGAL.

\subsubsection{Effect of FGAL on Phe-Sensitive $\mathrm{Ca}^{2+}$ Mobilization from Sarcoplasmic Reticulum (SR)}

After the stabilization period, Krebs solution was replaced by a $\mathrm{Ca}^{2+}$-free Krebs solution (with the addition of $3 \mathrm{mM}$ EDTA) for $10 \mathrm{~min}$, followed by phasic contractions with $10^{-6} \mathrm{M}$ Phe until depleting the intracellular $\mathrm{Ca}^{2+}$ stores in SR. The bath solution was replaced by Krebs solution for 15 min to promote the replenishment of $\mathrm{Ca}^{2+}$ stores. The $\mathrm{Ca}^{2+}$-free Krebs solution was replaced for $10 \mathrm{~min}$, and then two similar phasic contractions with $10^{-6} \mathrm{M}$ Phe (control) were induced. FGAL $\left(3 \times 10^{-6}, 10^{-5}\right.$, $3 \times 10^{-5}$ and $10^{-4} \mathrm{M}$ ) was incubated for $15 \mathrm{~min}$ at different concentrations and in different preparations, and another phasic contraction was evoked with $10^{-6} \mathrm{M}$ Phe [28]. The inhibition of the phasic contractions induced with Phe was calculated by comparing the contractile response in both the absence and presence of FGAL.

3.4.8. Effect of Phosphodiesterase (PDE) Inhibitors on Rat Aorta Pre-Contracted with Phe in Both Absence and Presence of FGAL

After the stabilization period, a contraction with $3 \times 10^{-7} \mathrm{M}$ Phe was evoked in both the absence (control) and presence of $3 \times 10^{-6} \mathrm{M}$ FGAL for $20 \mathrm{~min}$ [8]. During the sustained phase of the contraction, aminophylline $\left(10^{-10}\right.$ to $\left.10^{-3} \mathrm{M}\right)$, a non-selective PDE inhibitor, milrinone $\left(10^{-8}\right.$ to $\left.10^{-4} \mathrm{M}\right)$, a PDE III inhibitor, and sildenafil $\left(10^{-8}\right.$ to $\left.10^{-4} \mathrm{M}\right)$, a PDE V inhibitor [38], were added to the organ bath, in different experiments, to obtain a relaxation curve. Their relaxation potency was evaluated by comparing their $\mathrm{pD}_{2}$ values in both the absence and presence of FGAL.

\subsection{Statistical Analysis}

Data were expressed as the mean and standard error of the mean (S.E.M.). The negative logarithm of FGAL, Phe or $\mathrm{Ca}^{2+}$ concentration that produced a half-maximal response $\left(\mathrm{pD}_{2}\right.$, also denoted as $\left.\mathrm{pEC}_{50}\right)$ and the concentration of FGAL that inhibits $50 \%$ of maximal response to Phe or $\mathrm{CaCl}_{2}\left(\mathrm{IC}_{50}\right)$ were determined by non-linear regression $[49,50]$. Mean differences were statistically compared using Student's $t$-test, for two independent groups, or one-way ANOVA followed by Bonferroni's or Dunnett's post-test, for multiple comparisons. The null hypothesis was discarded when $p<0.05$. 
All values were obtained using GraphPad Prism ${ }^{\circledR} 5.01$ software (GraphPad Software Inc., La Jolla, CA, USA).

\section{Conclusions}

In this work, the mechanism underlying the vasorelaxant action of galetin 3,6-dimethyl ether in rat aorta was elucidated for the first time. This mechanism involves the noncompetitive antagonism of $\alpha_{1}$ adrenergic receptors and includes the non-selective opening of $\mathrm{K}^{+}$channels, the inhibition of $\mathrm{Ca}^{2+}$ influx through $\mathrm{Cav}$ or ROCs and the inhibition of intracellular $\mathrm{Ca}^{2+}$ release, which may be by direct or indirect mechanisms. Additionally, there is the involvement of cyclic nucleotide pathways, particularly through PDE V inhibition (Figure 10). Taken together, these data suggest that FGAL is a promising flavonoid to be used in the treatment of conditions associated with vascular smooth muscle disorders, such as hypertension or ischemia.

Figure 10. Overall study scheme representing the effect of FGAL on inducing rat aorta relaxation.

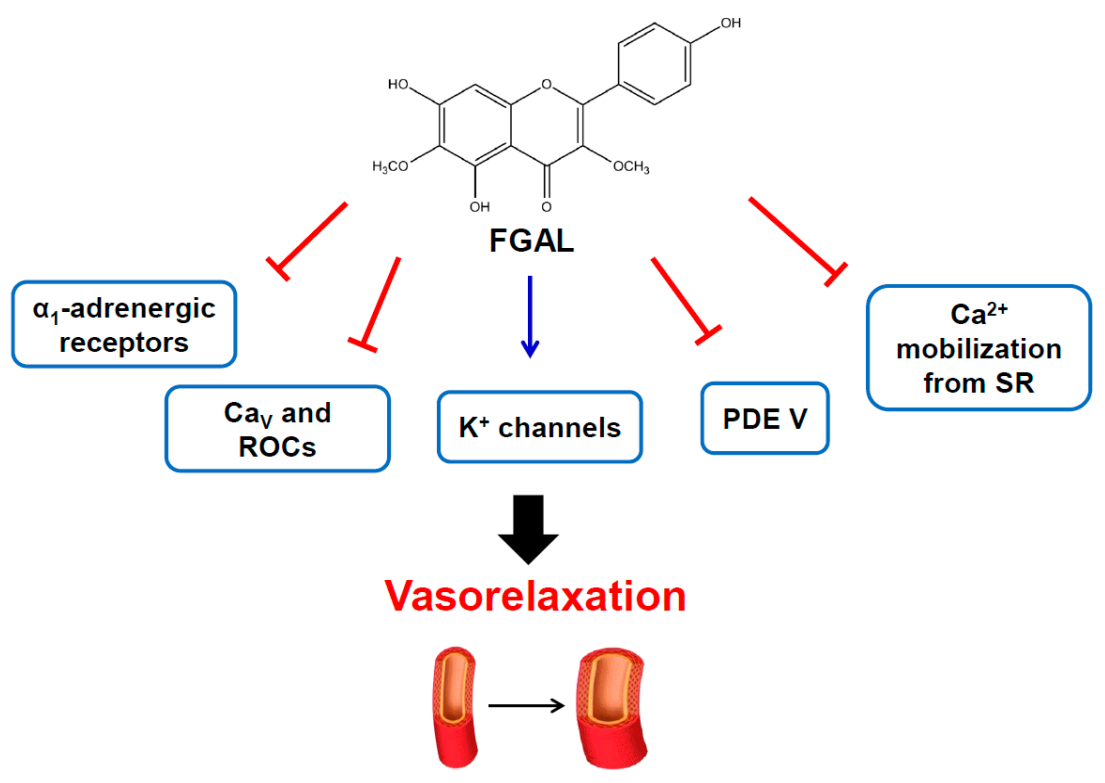

\section{Acknowledgments}

The authors thank José Crispim Duarte for providing technical assistance. This work was supported by Coordenação de Aperfeiçoamento de Pessoal de Nível Superior (CAPES) and Conselho Nacional de Desenvolvimento Científico e Tecnológico (CNPq), Brazil.

\section{Author Contributions}

C.L.M. and L.H.C.V. are the authors who mainly contributed to this research, performing pharmacological experiments, analysis of the data and writing the manuscript. A.C.C.C. was involved in experimental work and analysis of the data. I.R.R.M. was involved in drafting the manuscript. D.P.L. and B.V.O.S. performed the chemical isolation of the compound studied. F.A.C. and B.A.S. analyzed the data and interpreted the results. All authors read and approved the final manuscript. 


\section{Conflicts of Interest}

The authors declare no conflict of interest.

\section{References}

1. Perez-Vizcaino, F.; Duarte, J. Flavonols and cardiovascular disease. Mol. Asp. Med. 2010, 31, 473-494.

2. Queiroz, A.C.; Lira, D.P.; Dias, T.L.M.F.; Souza, E.T.; Matta, C.B.B.; Aquino, A.B.; Cavalcante-Silva, L.H.A.; Silva, D.J.C.; Mella, E.A.C.; Agra, M.F.; et al. The antinociceptive and anti-inflammatory activities of Piptadenia stipulacea Benth. (Fabaceae). J. Ethnopharmacol. 2010, 128, 377-383.

3. Grassi, D.; Aggio, A.; Onori, L.; Croce, G.; Tiberti, S.; Ferri, C.; Ferri, L.; Desideri, G. Tea, flavonoids and nitric oxide-mediated vascular reactivity. J. Nutr. 2008, 138, 1554S-1560S.

4. Grassi, D.; Desideri, G.; Croce, G.; Tiberti, S.; Aggio, A.; Ferri, C. Flavonoids, vascular function and cardiovascular protection. Curr. Pharm. Des. 2009, 15, 1072-1084.

5. Mladenka, P.; Zatloukalová, I.; Filipsky, T.; Hrdina, R. Cardiovascular effects of flavonoids are not caused only by direct antioxidant activity. Free Radic. Biol. Med. 2010, 49, 963-975.

6. Andriantsitohaina, R.; Auger, C.; Chataigneau, T.; Étienne-Selloum, N.; Li, H.; Martínez, M.C.; Schini-Kerth, V.B.; Laher, I. Molecular mechanisms of the cardiovascular protective effects of polyphenols. Br. J. Nutr. 2012, 108, 1532-1549.

7. Lima, J.T.; Almeida, J.R.G.S.; Barbosa-Filho, J.M.; Assis, T.S.; Silva, M.S.; Cunha, E.V.L.; Braz-Filho, R.; Silva, B.A. Spasmolytic action of diplotropin, a furanoflavon from Diplotropis ferruginea Benth., involves calcium blockade in guinea-pig ileum. Z. Naturforsch. B 2005, 60, 1093-1100.

8. Sato, Y.; He, J.X.; Nagai, H.; Tani, T.; Akao, T. Isoliquiritigenin, one of the antispasmodic principles of Glycyrrhiza ularensis roots, acts in the lower part of intestine. Biol. Pharm. Bull. 2007, 30, 145-149.

9. Elsohly, H.N.; El-Feraly, F.S.; Joshi, A.S.; Walker, L.A. Antiviral flavonoids from Alkanna orientalis. Planta Med. 1997, 63, 384.

10. Macêdo, C.L.; Vasconcelos, L.H.C.; Correia, A.C.C.; Martins, I.R.R.; Lira, D.P.; Santos, B.V.O.; Silva, B.A. Spasmolytic effect of galetin 3,6-dimethyl ether, a flavonoid obtained from Piptadenia stipulacea (Benth) Ducke. J. Smooth Muscle Res. 2011, 47, 123-134.

11. Török, J. Histamine-induced relaxation in pulmonary artery of normotensive and hypertensive rats: Relative contribution of prostanoids, nitric oxide and hyperpolarization. Physiol. Res. 2000, 49, 107-114.

12. Edwards, G.; Félétou, M.; Weston, A.H. Endothelium-derived hyperpolarizing factors and associated pathways: A synopsis. Pflug. Arch. 2010, 459, 863-879.

13. Chen, G.P.; Ye, Y.; Li, L.; Yang, Y.; Qian, A.B.; Hu, S.J. Endothelium-independent vasorelaxant effect of sodium ferulate on rat thoracic aorta. Life Sci. 2009, 84, 81-88.

14. Duarte, J.; Jimenez, R.; Villar, I.C.; Perez-Viscaino, F.; Jimenez, J.; Tamargo, J. Vasorelaxant effects of the bioflavonoid chrysin in isolated rat aorta. Planta Med. 2001, 67, 567-569. 
15. Picq, M.; Dubois, M.; Prigent, A.F.; Nemoz, G.; Pacheco, H. Inhibition of the different cyclic nucleotide phosphodiesterase isoforms separated from rat brain by flavonoid compounds. Biochem. Int. 1989, 18, 47-57.

16. Romero, M.; Jiménez, R.; Sánchez, M.; López-Sepúlveda, R.; Zarzuelo, M.J.; O’Valle, F.; Zarzuelo, A.; Pérez-Vizcaíno, F.; Duarte, J. Quercetin inhibits vascular superoxide production induced by endothelin-1: Role of NADPH oxidase, unclouped eNOS and PKC. Atherosclerosis 2009, 202, 58-67.

17. Scholz, E.P.; Zitron, E.; Katus, H.A.; Karle, C.A. Cardiovascular ion channels as a molecular target of flavonoids. Cardiovasc. Ther. 2010, 28, e46-e52.

18. Cogolludo, A.; Frazziano, G.; Briones, A.M.; Cobeno, L.; Moreno, L.; Lodi, F. The dietary flavonoid quercetin activates $\mathrm{BK}$ Ca currents in coronary arteries via production of $\mathrm{H}_{2} \mathrm{O}_{2}$. Role in vasodilatation. Cardiovasc. Res. 2007, 73, 424-431.

19. Khoo, N.K.; White, C.R.; Pozzo-Miller, L.; Zhou, F.; Constance, C.; Inoue, T.; Patel, R.P.; Parks, D.A. Dietary flavonoid quercetin stimulates vasorelaxation in aortic vessels. Free Radic. Biol. Med. 2010, 49, 339-347.

20. Webb, R.C. Smooth muscle contraction and relaxation. Adv. Physiol. Educ. 2003, 27, 201-206.

21. Baraban, J.M.; Gould, R.J.; Peroutka, S.J.; Snyder, S.H. Phorbol ester effects on neurotransmission: Interaction with neurotransmitters and calcium in smooth muscle. Proc. Natl. Acad. Sci. USA 1985, 82, 604-607.

22. Gleason, M.M.; Flaim, S.F. Phorbol ester contracts rabbit thoracic aorta by increasing intracellular calcium and by activating calcium influx. Biochem. Biophys. Res. Commun. 1986, 138, 1362-1369.

23. Alioua, A.; Mahajan, A.; Nishimaru, K.; Zarei, M.M.; Stefani, E.; Toro, L. Coupling of c-Src to large conductance voltage- and $\mathrm{Ca}^{2+}$-activated $\mathrm{K}^{+}$channels as a new mechanism of agonist-induced vasoconstriction. Proc. Natl. Acad. Sci. USA 2002, 99, 14560-14565.

24. May, L.T.; Leach, K.; Sexton, P.M.; Christopoulos, A. Allosteric modulation of G protein-coupled receptors. Ann. Rev. Pharmacol. Toxicol. 2007, 47, 1-51.

25. Nelson, M.T.; Quayle, J.M. Physiological roles and properties of potassium channels in arterial smooth muscle. Am. J. Physiol. 1995, 268, C799-C822.

26. Gurney, A.M. Mechanisms of drug-induced vasodilation. J. Pharm. Pharmacol. 1994, 46, 242-251.

27. Ko, E.A.; Han, J.; Jung, I.D.; Park, W.S. Physiological roles of $\mathrm{K}^{+}$channels in vascular smooth muscle cells. J. Smooth Muscle Res. 2008, 44, 65-81.

28. Zhu, X.M.; Fang, L.H.; Li, Y.J.; Du, G.H. Endothelium-dependent and -independent relaxation induced by pinocembrin in rat aortic rings. Vasc. Pharmacol. 2007, 46, 160-165.

29. Álvarez, E.; Campos-Toimil, M.; Justiniano-Basaran, H.; Lugnier, C.; Orallo, F. Study of the mechanisms involved in the vasorelaxation induced by (-)-epigallocatechin-3-gallate in rat aorta. Br. J. Pharmacol. 2006, 147, 269-280.

30. Iozzi, D.; Schubert, R.; Kalenchuk, V.U.; Neri, A.; Sgaragli, G.; Fusi, F.; Saponara, S. Quercetin relaxes rat tail main artery partly via a PKG-mediated stimulation of KCa1.1 channels. Acta Physiol. 2013 208, 329-339.

31. Nelson, M.T.; Huang, Y.; Brayden, J.E.; Hescheler, J.; Standen, N.B. Arterial dilations in response to calcitonin gene-related peptide involve activation of $\mathrm{K}^{+}$channels. Nature 1990, 344, 770-773. 
32. Guibert, C.; Marthan, R.; Savineau, J.P. Angiotensin II-induced $\mathrm{Ca}^{2+}$-oscillations in vascular myocytes from the rat pulmonary artery. Am. J. Physiol. 1996, 270, L637-L642.

33. Guibert, C.; Ducret, T.; Savineau, J.P. Voltage-independent calcium influx in smooth muscle. Prog. Biophys. Mol. Biol. 2008, 98, 10-23.

34. Horowitz, A.; Menice, C.B.; Laporte, R.; Morgan, K.G. Mechanisms of smooth muscle contraction. Physiol. Rev. 1996, 76, 967-1003.

35. Noguera, M.A.; Ivorra, M.D.; Chuliá, S.; D’ocon, P. Capacitative $\mathrm{Ca}^{2+}$ entry associated with $\alpha_{1}$-adrenoceptors in rat aorta. Naunyn Schmiedebergs Arch. Pharmacol. 1997, 356, 83-89.

36. Morello, S.; Vellecco, V.; Alfieri, A.; Mascolo, N.; Cicala, C. Vasorelaxant effect of the flavonoid galangin on isolated rat thoracic aorta. Life Sci. 2006, 78, 825-830.

37. Sammels, E.; Parys, J.B.; Missiaen, L.; Smedt, H.D.; Bultynck, G. Intracelular $\mathrm{Ca}^{2+}$ storage in health and disease: A dynamic equilibrium. Cell Calcium 2010, 47, 297-314.

38. Lugnier, C. Cyclic nucleotide phosphodiesterase (PDE) superfamily: A new target for the development of specific therapeutic agents. Pharmacol. Ther. 2006, 109, 366-398.

39. Bender, A.T.; Beavo, J.A. Cyclic nucleotide phosphodiesterases: Molecular regulation to clinical use. Pharmacol. Rev. 2006, 58, 488-520.

40. Rahimi, R.; Ghiasi, S.; Azimi, H.; Fakhari, S.; Abdollahi, M. A review of the herbal phosphodiesterase inhibitors: Future perspective of new drugs. Cytokine 2010, 49, 123-129.

41. Suenaga, H.; Kasuya, Y.; Kamata, K. Effects of calmodulin antagonist (W-7) on phorbol ester (PMA)-induced contractile response in isolated rat aorta. J. Smooth Muscle Res. 2001, 37, 1-7.

42. Dunne, A. Comparison of individual and cumulative dose-response curves [proceedings]. Br. J. Pharmacol. 1979, 67, 491P-492P.

43. Niu, L.G.; Zhang, M.S.; Liu, Y.; Xue, W.X.; Liu, D.B.; Zhang, J.; Liang, Y.Q. Vasorelaxant effect of taurine is diminished by tetraethylammonium in rat isolated arteries. Eur. J. Pharmacol. 2008, 580, 169-174.

44. Mishra, S.K.; Aaronson, P.I. A role for a glibenclamide-sensitive, relatively ATP-insensitive $\mathrm{K}^{+}$ current, in regulating membrane potential and current in rat aorta. Cardiovasc. Res. 1999, 44, 429-435.

45. Cole, W.C.; Clement-Chomienne, O.; Aiello, E.A. Regulation of 4-aminopyridine-sensitive, delayed rectifier $\mathrm{K}^{+}$channels in vascular smooth muscle by phosphorylation. Biochem. Cell Biol. 1996, 74, 439-447.

46. Van Der Staay, F.J.; Fanelli, R.J.; Blokland, A.; Schmidt, B.H. Behavioral effects of apamin, a selective inhibitor of the $\mathrm{SK}_{\mathrm{Ca}}$-channel, in mice and rats. Neurosci. Biobehav. Rev. 1999, 23, 1087-1110.

47. Fulton, D.J.R.; Hodgson, W.C.; Sikorski, B.W.; King, R.G. Attenuated responses to endothelin-1, $\mathrm{KCl}$ and $\mathrm{CaCl}_{2}$, but not noradrenaline, of aortae from rats with streptozotocin-induced diabetes mellitus. Br. J. Pharmacol. 1991, 104, 928-932.

48. Senejoux, F.; Girard, C.; Kerram, P.; Aisa, H.A.; Berthelot, A.; Bévalot, F.; Demougeot, C. Mechanisms of vasorelaxation induced by Ziziphora clinopodioides Lam. (Lamiaceae) extract in rat thoracic aorta. J. Ethnopharmacol. 2010, 132, 268-273. 
49. Jenkinson, D.H.; Barnard, E.A.; Hoyer, D.; Humphrey, P.P.A.; Leff, P.; Shankley, N.P. International Union of Pharmacology Committee on receptor nomenclature and drug classification. IX. Recommendations on terms and symbols in quantitative pharmacology. Pharmacol. Rev. 1995, 47, 255-266.

50. Neubig, R.R.; Spedding, M.; Kenakin, T.; Christopoulos, A. International Union of Pharmacology Committee on receptor nomenclature and drug classification. XXXVIII. Update on terms and symbols in quantitative pharmacology. Pharmacol. Rev. 2003, 55, 597-606.

Sample Availability: Samples of galetin 3,6-dimethyl ether are available from the authors.

(C) 2014 by the authors; licensee MDPI, Basel, Switzerland. This article is an open access article distributed under the terms and conditions of the Creative Commons Attribution license (http://creativecommons.org/licenses/by/4.0/). 